\title{
BEKERJANYA HUKUM TENTANG DESA DI RANAH PEMBERDAYAAN POLITIK, SOSIAL, DAN EKONOMI PEREMPUAN DESA ${ }^{1}$
}

\author{
Kushandajani* \\ * Government Science, Faculty of Social and Political Sciences, Diponegoro University, \\ Semarang, Indonesia. \\ ningkisworo123@gmail.com
}

\begin{abstract}
The issuance of Law No. 6/2014 on Village is expected to encourage village development, in which women are mentioned explisitly to be part of it. However, how it is realized, and to what extent it includes the political, social and economic dimension of women empowerment. Nondoctriner/qualitative research method was chosen and data collection techniques prioritized the use of in-depth interviews and FGD. The study found that number of women is still limited involved, either in its government structure and its village representative and still the secondary party in village decision making. In social area, women have given greater portion for education, health, legal aid, and poverty reduction. In terms of economy, women have tried to involve and encourage to take part in local economy as agriculture and home industries.. From this finding we can see that woman empowerment are mostly promoted in non-political areas.
\end{abstract}

Keywords: village government, woman empowerment, village law implementation, law in action.

\begin{abstract}
Abstrak
Kehadiran UU No. 6/2014 tentang Desa diharapkan berperan sebagai daya ungkit pembangunan desa, dimana secara eksplisit mengakui peran perempuan di dalamnya. Namun apakah perempuan yang tinggal di desa mampu menjawab persoalan ini melalui penelusuran tiga dimensi pemberdayaan perempuan yaitu politik, sosial, dan ekonomi ? Penelitian kualitatif nondoktriner dipilih dengan penggunaan teknik pengumpulan data wawancara mendalam dan FGD. Hasil penelitian menunjukkan di ranah politik keikutsertaan perempuan di struktur pemerintahan desa maupun di Badan Permusyawaratan Desa sangat sedikit dan tidak ambil peran penting dalam proses pengambilan keputusan. Dalam dimensi sosial, perempuan terlibat kuat di bidang pendidikan, kesehatan, pendampingan hukum, dan penanggulangan kemiskinan.. Dalam dimensi ekonomi perempuan juga kuat perannya dalam pengembangan ekonomi lokal, seperti pertanian dan industri rumah tangga. Simpulan riset menunjukkan bahwa pemberdayaan perempuan terlihat kuat di non-politik area.
\end{abstract}

Keywords: pemerintah desa, pemberdayaan perempuan, implementasi hukum, bekerjanya hukum.

\footnotetext{
${ }^{1}$ Bersumber dari penelitian dengan judul Investigating Gender Equality In Current Village Governance And Development: A Case Study In Lerep, Semarang District and Panggungharjo, Bantul District, 2014-2017, Sumber Dana: DIPA FISIP Undip 2017. Peneliti: Laila Kholid Alfirdaus, Kushandajani, dan Bulan Prabawani.
} 
A. Pendahuluan.

1. Latar Belakang.

Keberadaan UU No. 6 Tahun 2014 tentang Desa, memuculkan rasa pesimis dan juga optimis. Salah satu hal yang diatur dalam UU tersebut adalah keterwakilan perempuan dalam penyelenggaraan pemerintahan desa. Dalam pasal 26 ayat (4) menjelaskan salah satu kewajiban kepala desa adalah melaksanakan kehidupan demokrasi dan berkeadilan gender. Selanjutnya dalam pasal 63 disebutkan tentang kewajiban anggota Badan Permusyawaratan Desa (BPD) yang salah satunya adalah melaksanakan kehidupan demokrasi yang berkeadilan gender dalam penyelenggaraan pemerintahan desa. Secara lebih eksplisit pasal 58 menyebutkan bahwa keanggotaan BPD didasarkan pada wilayah, perempuan, penduduk, dan kemampuan keuangan desa. Selanjutnya dalam Peraturan Pemerintah (PP) No. 43 tahun 2014 tentang desa pasal 121 ayat (2) menyebutkan secara jelas tentang kegiatan pembangunan desa yang harus ditetapkan berdasarkan keadilan gender, pasal 72 ayat (1) yang menyebutkan pengisian keanggotaan BPD dengan menjamin keterwakilan perempuan, serta pasal 80 ayat (3) yang menyebutkan perwakilan kelompok perempuan merupakan salah satu unsur masyarakat yang ikut serta dalam proses pengambilan keputusan tertinggi di desa, yaitu musyawarah desa. Apa yang tertera dalam pasal-pasal tersebut merupakan janji hukum yang harus dipenuhi, karena paradigma hukum sekarang bergerak di dua aras yaitu legal service dan legal process(Susskind, 1996)

\section{Kerangka Teori.}

Sebagaimana yang disampaikan Roscoe Pound bahwa hukum itu bukanlah suatu keadaan melainkan suatu proses yang berhubungan dengan fakta-fakta sosial. Efektivitas bekerjanya hukum lebih ditekankan, yang mementingkan beroperasinya hukum di dalam masyarakat.(Sinha, 1993) Konsep social engeneering diperkenalkan sebagai fungsi utama dalam hukum. Pengertian "law in the books" dibedakan dari "law in action". Untuk dapat memenuhi peran hukum sebagai rekayasa sosial Roscoe Pound lalu membuat penggolongan atas kepentingankepentingan yang harus dilindungi oleh hukum itu sendiri, yaitu sebagai berikut: (D.S. Andriansyah, 2015)

1. Kepentingan Umum (Public Interest)

2. Kepentingan negara sebagai Badan Hukum

3. Kepentingan negara sebagai penjaga kepentingan masyarakat.

4. Kepentingan Masyarakat (Social Interest)

5. Kepentingan akan kedamaian dan ketertiban

6. Perlindungan lembaga-lembaga sosial

7. Pencegahan kemerosotan akhlak 
8. Pencegahan pelanggaran hak

9. Kesejahteraan sosial.

10. Kepentingan Pribadi (Private Interest)

11. Kepentingan individu

12. Kepentingan keluarga

13. Kepentingan hak milik.

Hal ini sejalan dengan pemikiran Satjipto Rahardjo yang melihat hukum juga sebagai rekayasa sosial, dimana hukum dipandang sebagai instrumen untuk melakukan perubahan sosial.(Rahardjo, 2006) Hukum menjadi sarana yang sarat dengan keputusan politik. UU No. 6 tahun 2014 tentang Desa jelas merupakan keputusan politik karena dibuat oleh lembaga politik yang memiliki otoritas membentuk hukum. Bunyi pasal-pasal yang ada diharapkan bisa menggerakkan semua lapisan masyarakat desa untuk bisa mewujudkan masyarakat desa yang lebih sejahtera dan berkeadilan. Usaha tersebut bisa diwujudkan melalui pembangunan desa yang melibatkan semua lapisan masyarakat, termasuk kaum perempuan. Hal ini selaras dengan fungsi hukum untuk memelihara kepentingan umum dalam masyarakat, menjaga hak-hak manusia, dan mewujudkan keadilan dalam hidup bersama. (Huijbers, 1982). Keberadaan UU No. 6 Tahun 2014 tentang Desa jelas berimplikasi terhadap tatanan masyarakat desa, yang membawa dinamika hubungan antara anggota-anggota masyarakatnya. Keberadaan UU tersebut sebagai pedoman atau dasar bertindak masyarakat dan pemerintah desa dalam menjalankan pembangunan desa. Bagimanapun kemajuan ilmu pengetahuan termasuk ilmu hukum (the science of law atau legal science) terletak pada seberapa tinggi atau rendah kredibilitas ilmu pengetahuan, nilai akseptasi, dan espektasi yang dapat dipetik oleh dan di dalam memajukan kehidupan suatu masyarakat dalam kurun waktu tertentu.(Atmasasmita, 2012)

Bank Dunia mendifiniskan persamaan gender sebagai persamaam akses antara lakilaki dan perempuan baikn di bidang pendidikan, kesehatan dan aset, dan kesempatan untuk mendapat penghasilan dan menadi agen dalam pembangunan dan pengambilan keputusan, begitu juga untuk mendapatkan kesejahteraan. Dengan demikian persamaan gender tidak hanya berhubungan dengan proses namun juga hasil, dimana laki-laki maupun perempuan sama-sama terlibat dalam proses pengambilan keputusan dan pembangunan. Hal penting dalam pembangunan dan kebijakan, sebagaimana pendapat Kabeer and Natali (Kabeer, Naila and Natali, 2013) secara empiris terbukti berkontribusi bagi pengurangan kemiskinan dan peningkatan kesejahteraan. Pemberdayaan politik mengacu peran perempuan dalam proses pengambilan keputusan di desa, pemberdayaan sosial perempuan mengacu pada peran perempuan dalam bidang 
pendidikan, kesehatan ibu dan anak, bahkan penanggulangan kemiskinan. Adapun pemberdayaan ekonomi perempuan melihat peran perempuan dalam proses ekonomi seperti yang terwadahi dalam UMKM (ternasuk industri rumah tangga) dan Badan Usaha Milik Desa (BUMDesa).

\section{Kebaruan Penelitian}

Ada dua konsep utama dalam riset ini, yaitu bekerjanya hukum dan pemberdayaan perempuan, dimana masing-masing sering dikaji tersendiri. Riset ini mencoba menghubungkan kedua konsep tersebut dalam kajian yang lebih spesifik, yaitu berlakunya UU Desa dalam pemberdayaan perempuan di desa. Kajian-kajian terdahulu mengenai berlakunya hukum bisa disimak dalam hasil-hasil riset diantaranya melihat keberadaan UU No. 6 Tahun 2014 tentang Desa dalam perspektif UUD 1945 Pasal 18 B, ayat (2) (Nurcholis, 2014), Hasil riset tersebut merekomendasi agar dilakukan rektrukturisasi keberadaan pemerintah desa, agar menjadi bagian integral pemerintah daerah. Hal ini justru berbeda dengan temuan riset lain yang justru lebih menekankan otonomi desa. (Kushandajani, 2016b) Keberadaan UU No. 6 Tahun 2014 telah menjamin otonomi desa dengan diakuinya dua kewenangan desa yaitu kewenangan hak asal usul dan kewenangan lokal berskala desa. Dengan diakuinya kewenangan desa tersebut, berimplikasi pada penyelenggaraan pemerintahan desa yang otonom dengan melihat beberapa kriteria: desa membuat peraturan desa, menyusun perencanaan pembangunan desa sampai APBDesa, memilih pemimpinnya (kepala desa) secara langsung, dan mendapatkan Dana Desa sebagai bagian daru sumber keuangan desa. (Kushandajani, 2016a). Studi tentang implementasi UndangUndang No.6 Tahun 2014 tentang Desa dalam pelaksanaan tugas kepala desa di Desa Gemar Baru, Kecamatan Muara Ancalong, Kabupaten Kutai Timur juga bertujuan menunjukkan bagaimana hukum berupaya menjelaskan fenomena sosial tentang pemerintahan desa dan bagaimana seharusnya dilaksanakan. (Welly, 2016) Dengan demikian kehadiran UU No, 6 tahun 2014 tentang Desa merupakan pendayagunaan hukum untuk kepentingan pembangunan nasional, baik dalam praktik pembangunan dan pembinaan hukum nasional, (Marbun, 2014) atau bisa saja seperti yang disampaikan Sandefur "We might say that there are situations where law's action includes the creation of its subjects' inaction, sometimes to those subjects' great harm or lingering disadvantage" (Sandefur, 2015)

Kajian pemberdayaan perempuan sebenarnya cukup banyak dilakukan, dari pemahaman konsep pemberdayaan perempuan sebagaimana dilakukan Rahman "Long before the word 'empowerment' became popular, women were speaking 
about gaining control over their lives, and participating in making the decisions that affect them in home and community, in government and international development policies"(Rahman, 2013) sampai pemberdayaan perempuan dengan berbagai dimensi yang menyertainya di Pakistan dimana temuan terpenting adalah berlakunya konsep pemberdayaan perempuan memiliki konotasi makna yang berbeda-beda tergantung pada konteks sosial, ekonomi, dan politik dimana konsep tersebut digunakan.(Mujahid, Ali, Noman, \& Azeema Begum, 2015) Demikian pula yang dilakukan oleh Nayak menghasilkan temuan penting bahwa "The study reveals that women of India are relatively disempowered and they enjoy somewhat lower status than that of men in spite of many efforts undertaken by government". (Nayak \& Bidisha Mahanta, 2009) Perempuan India memiliki akses minim dalam pendidikan dan pekerjaan. Padahal sejatinya pendidikan merupakan faktor kunci bagi pemberdayaan perempuan menuju kemakmuran, pengembangan diri dan kesejahteraan. (Sundaram, S., Sekar, M., and Subburaj, 2014) Peranserta pemerintah dalam pemberdayaan perempuan memang sangatlah kuat, karena melalui kebijakan hukum (legal policy) yang dihasilkan akan bisa terwadahi aksi pemberdayaan secara nasional, sebagaimana yang disarankan Alfirdaus dalam riset terakhir "There is thus a crucial need for the national government to issue regulations that will encourage the stronger assertion of gender equality in village law implementation". (Alfirdause \& Kushandajani, 2017)

Berdasarkan latar belakang yang ada, maka rumusan penelitian mencakup tiga hal: (a) bagaimana bekerjanya hukum di ranah pemberdayaan politik perempuan ?; (b) bagaimana bekerjanya hukum di ranah pemberdayaan sosial perempuan: (c) bagaimana bekerjanya hukum di ranah pemberdayaan ekonomi perempuan? Dengan demikian tujuan penelitian adalah menganalisis bekerjanya hukum tentang desa di tiga ranah pemberdayaan perempuan: politik, sosial, dan ekonomi.

\section{B. Metode Penelitian}

Konsekwensi tidak ada konsep tunggal mengenai apa yang disebut dengan hukum dan fungsinya adalah pada perbedaan dalam metode kajiannya. (Wignjosoebroto, 2002) Penelitian ini termasuk ke dalam kategori socio-legal research. Penggunaan teori ilmu-ilmu sosial (termasuk di dalamnya sosiologi, ilmu politik, dan ekonomi) di dalam mendapatkan tempatnya dalam sociolegal studie, karena Ilmu hukum dan ilmuilmu sosial mempunyai hubungan yang saling melengkapi dan saling mempengaruhi. (Warassih, 2005) Studi tentang hukum dan institusi legal dari perspektif ilmu sosial dilakukan untuk 
menerangkan masalah hukum.(Luhmann, 1985)(Hunt, 1993)(Turkel, 1996)

Penelitian ini mengutamakan perspektif emic, artinya mementingkan pandangan informan, yakni bagaimana ia memandang dan menafsirkan dunia dari pendiriannya.(Nasution, 1996) Dengan demikian, hasil penelitian ini tidak dimaksudkan mencari generalisasi dikarenakan temuan bergantung pada interaksi antara peneliti dan subjek penelitian, dimana pelaku-pelaku mendapat tempat untuk memainkan peranannya.(Ashshofa, 2004) Teknik pengumpulan data mengutamakan penggunaan data langsung (fisrt hand) yang diperoleh dari beberapa nara sumber melalui teknik wawancara mendalam (depth interview) dan diskusi kelompok terbatas (focussed group discussion/FGD). Informan atau narasumber terdiri dari para aktivis perempuan desa dan pemerintah desa (kepala desa dan perangkat desa). Instrumen utama adalah peneliti sendiri (human instrument), sedangkan analisis data pada prinsipnya berproses secara induksi interpretasi - konseptualisasi. Lokasi penelitian mencakup Desa Lerep, Kabupaten Semarang, Propinsi Jawa Tengah dan Desa Panggungharjo, Kabupaten Bantul, Daerah Istimewa Yogyakarta.

\section{Hasil dan Pembahasan}

\section{Bekerjanya Hukum di Ranah}

\section{Pemberdayaan Politik Perempuan}

Secara umum pemberdayaa politik perempuan di Desa Lerep dari aspek kuantitas cukup baik, dimana kepala desa ikut mendorong keaktifan perempuan dalam proses pengambilan keputuasn di desa (musyawarah desa) mencapai $30 \%$ kehadiran. Namun saat rembug desa dilakukan, sangat minim perempuan ikut ambil bagian dalam pengajuan gagasan apalagi ikut memutuskan. Adapun di Badan Permusyawaratan Desa (BPD) anggota perempuan hanya satu orang diantara sembilan orang anggota BPD.

"Paling susah itu mencari anggota BPD. Kemarin ada anggota BPD yang meninggal saja ditawar-tawarkan susah, akhirnya kita main tunjuk saja. Ditawarkan ke masyarakat itu, sudah dirembug di musyawarah dusun, karena kita berusaha supaya penyebarannya merata jadi ada delegasi dari dusun, sudah dirembug itu akhirnya mengundurkan diri. Itu laki-laki, apalagi perempuan. Jadi cuma Mbak Ratna saja perempuannya. Backgroundnya ibu rumah tangga, tapi suaminya wartawan Suara Merdeka jadi linknya cukup kuat" (Sumariyadi, Kepala Desa Lerep)

Pemerintah desa sendiri lebih banyak diisi oleh laki-laki dibandingkan perempuan. 
Jumlah perempuan yang mengisi posisi perangkat desa adalah tiga orang, masingmasing sebagai sekretaris desa, bendahara desa, dan Kepala Urusan (Kaur) perencanaan. Sekretris desa baru terpilih dua bulan yang lalu melalui proses rekruitmen perangkat desa. Secara kuantitatif yang mendaftar menjadi sekretaris desa sebagian besar adalah perempuan.

"Saya malah cenderung pilih perempuan karena nyuwunsewu, stories kesejahteraan perangkat desa untuk saat ini paling tidak setara UMK atau di bawah UMK. Kalau saya malah menginginkan perangkatperangkat ini perempuan yang suaminya sudah mapan, jadi untuk supporting saja. Dan saya mulai sebelum daftar saya sampaikan 'di sini niatnya tidak kerja, tetapi ngabdi, kalau mau silahkan kalau nggak ya sudah.' Sampai tak kasih ilustrasi kalau di keraton itu gimana, kalau abdi keraton itu berapa dikasihnya 'ganjaran' sama raja. Mereka nggak mengharap ganjaran dari raja tetapi mengharap berkahnya" (Sumariyadi, Kepala Desa Lerep)

Hambatan apa yang paling sering muncul terkait partisipasi perempuan dalam pembangunan desa adalah masih kuatnya budaya turunan nenek moyang yang mengajarkan bahwa perempuan itu ibaratnya kanca wingking ${ }^{2}$. Kepala desa melakukan sosialisasi dan dorongan sampai ke RT saat ada acara pemilihan kepala dusun (Kadus) agar perempuan ikut mencalonkan diri menjadi Kadus.

Kondisi agak berbeda dialami Desa Panggungharjo, dimana jumlah perangkat desa perempuan lebih banyak, mencapai 12 orang sementara laki-laki mencapai 25 orang. Perangkat desa perempuan menduduki posisi sekretaris desa, Kaur keuangan, staf desa dan staf honorer. Hal ini berbanding terbalik dengan keberadaan anggota BPD, dimana perempuan tidak terwakili sama sekali. Namun demikian, keikutsertaan perempuan dalam pengambilan keputusan cukup tinggi mengingat sudah terciptanya pemahaman dasar tentang prioritas pembangunan desa. Prioritas pembangunan desa di Panggungharjo telah berubah, lima tahun lalu prioritas di bidang pemerintahan yaitu memperbaiki sumber daya manusia perangkat desa, kalau sekarang pada pelayanan dasar ke masyarakat.

"Kalau untuk Musrenbangdes (Musyawarah Rencana Pembangunan Desa) itu kan dibagi tiga tim pas Musrenbangduk (Musyawarah Rencana Pembangunan Dukuh), nah setiap

\footnotetext{
${ }^{2}$ Perempuan diposisikan sebagai pihak yang menjalankan fungsi domestik seperti mendidik anak, memasak, dan pekerjaan rumah lainnya.
} 
tim itu pasti ada perempuannya Mbak. Seperti saya ini kan perempuan, atau Bu Kaur Keuangan ini juga perempuan, ya kita aktif dalam forum tersebut. Kalau yang dihadirkan pada saat Musrenbang itu ya ada PKK, Kader kesehatan, dari perwakilan pedukuhan. Biasanya mereka membawa permasalahan, masalah pendidikan misalnya putus sekolah, masalah kesehatan remaja, kehamilan diluar nikah. Karena kebetulan Desa Panggungharjo ini paling banyak kasus kehamilan diluar nikah se Kabupaten Bantul Mbak. Usulan programnya misalnya Posbindu (Pos Bimbingan Terpadu)" (Yuli Trisniati, Carik Desa Panggungharjo)

Mekanisme pengusulan program tiap pokja sesuai dengan mekanisme pemerintah desa, melalui skema musrenbang yang dilakukan satu tahun sekali.

"Karena sekarang tidak bisa langsung "sak-dek-sak nyek” karena UU Desa mensyaratkan seperti itu ya kita rapat kerja program itu ya sebelum musrenbang tingkat desa itu dilakukan, kita mengusulkan sampai ke besarannnya. Nanti biasanya yang di acc seperti apa itu sebagai pegangan kita untuk melaksanakan program di tahun berjalan. Karena kesadaran pemberdayaan dan kesadaran swadayanya besar itu ya kadang mlenceng-mlenceng mereka mau, umpama mau mengambil uang kas seperti itu bisa untuk melakukan programseperti apa... “(Umi Hani’ah, Ketua PKK Desa Panggungjarjo)

PKK memiliki perwakilan dalam tim yang ikut sosialisasi ke dusun-dusun. Nanti program PKK Desa disinkronkan juga dengan kebutuhan PKK Dusun, baru disampaikan ke musrebang. Seringkali ibuibu mayoritas nyambi jika ada waktu sebelum musrenbang dibahas dulu secara informal. Biasanya perwakilan PKK yang ikut musrenbang hanya satu orang saja namun sudah membawa program prioritas yang sudah matang. Umumnya PKK sudah lebih dulu tahu perkiraan anggaraan, lalu dibagi untuk pemberdayaan dan program lain. Jika keluar dari nilai yang sudah direncanakan PKK harus ambil skala prioritas. Kadangkala program yang sudah diajukan direview kembali, bahkan tidak hanya sekali. Saat musrenbang bahkan masih menjaring aspirasi untuk nantinya dikerucutkan lagi.

Perbedaan yang paling dirasakan sebelum dan sesudah UU Desa adalah bantuan itu tidak langsung turun dalam bentuk uang, tapi berupa fasilitasi program. PKK akan menyampaian program dengan rincian waktu dan biaya sesuai APBDesa kepada Pemerintah Desa, nanti pemerintah 
desa yang menyiapkan. Jadi enak sekarang. Berbeda dengan sebelum ada UU Desa, dimana PKK diberi anggaran semisal limapuluh juta pertahun, dan dikelola sendiri untuk program. Para penggiat PKK melihat perubahan ini lebih baik dan lebih akuntabel dibanding sebelumnya.

Hambatannya dalam penyusunan maupun pelaksanaan program PKK antara lain: (1) SDM PKK banyak yang lansia sehingga sering tidak produktif, sementara yang muda-muda masih belum memiliki ketertarikan dalam pengelolaan PKK; (2) pemerintah desa, karena memang cakupan yang dilayani cukup luas, kadang dalam pelaksanaan program kurang maksimal, misal dalam pengadaan barang dan jasa; (3) data kurang terintegrasi, satu bagian dengan bagian yang lain datanya sendiri-sendiri; (4) para pengurus PKK seringkali tersita waktunya untuk mengurusi arisan dan simpan pinjam sehingga sering tidak fokus dalam pengembangan program yang lebih inovatif, juga kelemahan dalam kaderisasi.

Keberadaan Dana Desa (DD) sangat dirasakan kemanfaatannya di kedua desa, karena kegiatan PKK misalnya dimasukkan dalam APBDesa bersumber dari DD. Untuk mendukung kegiatan desa, perempuan yang tergabung dalam PKK Pedukuhan (dusun) juga berkontribusi besar dalam pelaksanannya.

\section{Bekerjanya Hukum di Ranah Pemberdayaan Sosial Perempuan}

Dibandingkan ranah politik, bekerjanya hukum di ranah sosial sangat berbeda. Situasi menjadi terbalik, dimana peran perempuan sangat kuat di semua sektor sosial seperti kesehatan, pendidikan, dan penanggulangan kemiskinan. Di Desa Lerep ada forum kesehatan desa, dimana yang terlibat dalam forum kesehatan desa 99\% adalah perempuan ...”karena yang bapak-bapak ternyata malah tidak telaten" (Sulis, aktivis Desa Lerep). Forum kesehatan desa itu setiap sebulan sekali mengadakan pertemuan, melakukan monitoring seperti angka kematian anak, angka kematian bayi, kemungkinan ada warga yang terkena HIV, dan mendiskusikan solusi penanganannya.

Untuk program Pos Pelayanan Terpadu (Posyandu) ada kendala pendanaan, karena ketidakjelasan kewenangan antara pemerintah daerah kabupaten dan pemerintah desa. Posyandu adalah program yang datang dari Dinas Kesehatan Kabupaten. Saat DD masuk ke desa, ada ide agar Posyandu dikelola mandiri oleh desa melalui penganggaran yang bersumber dari DD. Hal ini menimbulkan masalah karena ketidak konsistenan pemerintah kabupaten dalam mengelola program Posyandu. ...."Sampai pengurus posyandu semuanya dicrosscheck, terimanya double nggak. Jadi masalah pembagian kewenangan itu masih belum fixed, belum diatur dalam perda sehingga kalau seperti kita hanya gagap- 
gagap saj" (Indarsih, Bendahara Desa Lerep). Selain itu ada Forum Remaja Putri yang yang bergandeng dengan PKK dan didanai lewat DD yang khusus mewadahi konsultasi reproduksi remaja, dan diskusi masalah seks sehat.

Pada bidang pendidikan keberadaan Pendidikan Anak Usia Dini (PAUD) ratarata yang mengelola adalah perempuan. PAUD di Desa Lerep ada tujuh, dan semuanya merupakan bagian dari program PKK Desa. PKK yang merintis, dan melakukan pengkaderan pendamping sekaligus pengembangan sumber daya pendidiknya. Awalnya tenaga pendidik hanya lulusan SMA, sekarang ditingkatkan menjadi Diploma pendidikan khusunya pendidikan PAUD.

Dalam mengatasi Kekerasan Dalam Rumah Tangga (KDRT) peran perempuan juga sangat kuat, meski sering menghadapi kendala dalam pelaksanaanya:

"Iya, wong KDRT saja yang saya tau saya panggil, iki wis keterlaluan, wis KDRT $i k i$, ayo diproses, tetap nggak mau. Warga saya tuh sempat pipinya diseterika sama suaminya saat sedang marah. Itu saya sudah ngotot, ini harus dimasukne, tetep nggak mau. Saya tanya alasannya kasihan anaknya, jika nanti bapaknya jadi napi." (Sulis, aktivis)

Di bidang pengentasan kemiskinan, Program Nasional Pemberdayaan
Masyarakat (PNPM-Perkotaan) saat ini berganti nama menjadi Program KOTAKU (Kota Tanpa Kumuh) di bawah kendali Dirjen Cipta Karya. Ini merupakan progam pemerintah pusat yang beroperasi di desa. Smua pendanaan dari Pusat namun pengelolaan di tangan Badan Keswadayaan Masyarakat (BKM) hasil bentukan PNPMPerkotaan. Hampir separuh pengurus sekaligus relawan BKM Desa Lerep adalah perempuan.

Di Desa Panggungharjo aktivitas sosial perempuan juga sangat tinggi, dengan banyaknya lembaga-lembaga permberdayaan perempuan yang tumbuh. Secara struktural yang berhubungan dengan pemerintah adalah PKK, dari tingkat desa sampai ke tingkat dasawisma. Kegiatan perempuan terkait keagamaan juga banyak, dimana tiap masjid di tiap dusun dipastikan ada kegiatan pengajian kelompok perempuan. Demikian pula dengan perempuan usia lanjut aktif dalam kelompok lansia dengan kegiatan senam, panembromo , pengajian, dan lainnya.

Saat ini program utama PKK Panggungharjo adalah pencegahan dan penanggulangan KDRT dan kehamilan tidak diinginkan. Upaya yang sudah dan sedang dilakukan bersifat terintegral, anaknya dibina kemudian orang tua yang mempunyai anak di usia-usia remaja juga di bina. Ini tidak terbatas pada kelompok perempuan, bapak-bapak juga dilibatkan. Keberadaan 
Kelompok Pendamping (KP) ibu-ibu hamil dan menyusui sangat bermanfaat dan mendorong ibu-ibu untuk menyusui bayinya minimal 6 bulan (ASI eksklusif).

Di bidang pendidikan, Desa Panggungharjo memiliki program "satu rumah satu sarjana". Di Dusun Cabeyan ada satu anak yang lolos seleksi karena memenuhi syarat secara akademik pandai dan berasal dari keluarga tidak mampu. Adapun di bidang keagamaan ada beberapa kelompok pengajian seperti kelompok Suryo Condro punya Muhammadiyah biasanya pengajian, ada Muslimat NU kegiatannya tasmiul Quran, dan LDII difasilitasi desa untuk pembangunan masjid.

Untuk perlindunga hukum, Desa Panggungharjo memilik Lembaga Mediasi Desa (LMD) yang beranggotakan pengacara-pengacara yang berdomisili di Desa Panggungharjo. Ini kita fasilitasi, jadi kalau ada permasalahan hukum di warga, tidak sebatas pada perempuan itu bisa di selesaikan di Desa, jadi jangan sampai maju ke ranah hukum. Untuk akses ke lembaga mediasi desa ini digratiskan, warga tidak dipungut biaya. Desa sekadar ngasih honor ke LMD kalau ada permasalahan.

Adapun untuk pemberdayaan masyarakat dalam penanggulangan kemiskinan, Desa Panggungharjo menganggarkan bantuan untuk Rumah Tidak Layak Huni (RTLH). Data terbaru dari kementrian PU ada 63 KK yang dapat
RTLH, selain itu dari BKK (bantuan khusus keuangan) ada $37 \mathrm{KK}$, lalu $133 \mathrm{KK}$ mendapat bantuan dari Desa. (Nur Haryanta, Kasi Kesejahteraan Desa Panggungharjo)

\section{Bekerjanya Hukum di Ranah Pemberdayaan Ekonomi \\ Perempuan}

Kelompok Wanita Tani (KWT) Sumber Hasil di Dusun Lerep memiliki produk andalan sabun susu karena Desa Lerep penghasil susu perah. Kemudian KWT Manggar Lestari yang ada di Dusun Indrakila lebih banyak produk seperti gula aren, kolang-kaling, jahe instan.

"Anggota KWT rata-rata berusia 30an keatas, ibu-ibu sedanten. Wonten ingkang sampun sepuh. Dibagi-bagi nek KWT menika misal wonten ingkang badhe ndamel permen susu menika piyambak, ingkang ndamel krupuk piyambak, pembibitan piyambak"(Ratni, Direktur BUMDes Lerep)

Selain KWT, di Desa Lerep juga sudah terbentuk BUMDES dengan nama Gerbang Lentera (singakatan dari Gerakan Pembangunan Desa Lerep Aman Tenteram Sejahtera). BUMDES ini memiliki cabang produksi catering, pengelolaan sampah berbasis komunitas, pariwisata, perikanan, dan pertanian. Unit kerjanya ada lima: pengelolaan sampah, catering, perikanan dan peternakan, kemudian ada LKM (Lembaga 
Keuangan Mikro), dan Warung Serba Ada (Waserda). Jantungnya BUMDES justru di kegiatan-kegiatan yang dimotori para perempuan. Keberadaan UU No. 6 Tahun 2014 berimplikasi positif bagi terbentuknya pusat-pusat ekonomi yang dikelola melalui BUMDES. Awalnya masyarakat memang bersikap skeptis terhadap keberadaan BUMDES, namun setelah melihat hasilnya memberikan tambahan pendapatan keluarga maka sikap masyarakat makin positif.

Di Desa Panggungharjo ada 1 KWT Desa dengan nama Sumber Rejeki. Anggota aktf ada 30 perempuan, tetapi yang benar-benar aktif ada 22 orang dengan rentang usia 30 - 65 th. (Andar Arwiyati, Pengurus KWT Desa) Usaha ekonomi produktifnya masih berpusat pada pertanian rumah tangga. Desa menyediakan lahan khusus untuk KWT yang ditanami sayuran, kemudian untuk pemeliharaan tanaman, panen, olahan hasil , sampai pembibitan ulang dilakukan secara bergilir diantara anggota kelompok. Untuk pemasaran hasil pertanian, selain menggunakan pasar yang sudah ada juga disertakan dalam kegiatan desa, kecamatan dan dinas pertanian maupun dinas perdagangan kabupaten dalam bentuk bazaar khusus hasil-hasil pertanian desa.

Bumdes Panggungharjo berdiri pada tahun 2013, fokus pada tiga bidang yaitu sampah, agroenergi, dan swalayan desa (swadesa). Manajerialnya ketua, sekretaris, bendaraha, staff, dan beberapa merangkap manajer unit. Semuanya hanya 7 orang, 5 orang laki-laki dan 2 orang perempuan. Bumdes dipandu oleh dua visi, yang pertama itu visi membangun kemandirian desa dengan meningkatkan PADes, yang kedua menghadirkan negara dalam masyarakat desa. Jadi bumdes tidak hanya berorientasi pada profit, tapi juga pada benefit. Benefit yang dimaksud adalah menyangkut permasalahan mendasar seperti pangan, air, dan sampah. Sehingga dari dua visi tersebut diturunkan menjadi dua fungsi yaitu fungsi sosial dan fungsi ekonomi. Fungsi sosial dalam proses pemberdayaan juga harus melibatkan masyarakat. Karena prinsipnya, Bumdes adalah lembaga yang menjadi media demokrasi ekonomi lokal.

Ibu-ibu PKK terlibat dalam proses pemberdayaan karena mereka, dilihat dari sisi waktu dan psikologisnya, lebih memiliki waktu luang daripada laki-laki disebabkan wanita karir sangat terbatas di desa dibandingkan di perkotaan. Dengan demikian mitra utama Bumdes adalah ibuibu PKK, utamnya di unit usaha pengelolaan sampah (KUPAS) dan agroenergi. Pelanggan KUPAS itu ada 1700 KK. Dari jumlah tersebut, $960 \mathrm{KK}$ dikelola bumdes, sementara $500 \mathrm{KK}$ dikelola secara mandiri oleh masyarakat, dan sisanya merupakan mitra untuk transit tempat pembuangan sampah. Mitra ini biasanya penarik sampah lokal yang numpang transit memindah 
sampah ke TPA. Kemudian PKK bertugas untuk memilah sampah dari sumbernya agar lebih efektif dan efisien, selain juga dalam rangka mengedukasi masyarakat untuk sadar lingkungan. Mekanismenya, kita sediakan kantong pilah serta bank sampah di setiap RT, walaupun pada praktiknya belum semua RT memiliki bank sampah ini. Jadi tiap hari minggu, mereka nabung sampah layak jual. Sementara yang diambil harian adalah sampah kering dan organik.

Bank sampah yang dikelola PKK tersebut juga berperan sebagai penyuplai kebutuhan sisa minyak goreng (jlantah). Pada tahun 2016 bank sampah mengirim 4000 liter ke perusahaan-perusahaan. Sisa minyak goreng tersebut merupakan sisa minyak yang sudah tidak layak pakai, dikupulkan dari rumah tangga-rumah tangga

"PKK berposisi sebagai perantara untuk membayarkan retribusi, karena kalau door to door menariki iuran dari setiap warga sementara ada 1700 KK itu tidak efisien. Timbal baliknya adalah, pendapatan di area PKK yang bersangkutan dipotong 10\% untuk diberikan ke kas PKK. Ketiga, Perbedaannya terkait uang penyertaan modal, kalau dulu itu hanya bisa diambilkan dari PADes, kalau sekarang bisa diambilkan dari Dana Desa. selanjutnya terkait dengan legalitas, dimana terdapat perubahan peraturan mentri, jadi kalau peraturannya berubah, kita menyesuaikan. Dulu penyertaan modal bisa dari CSR atau pihak ketiga, kalau sekarang dari ADD dan DD. Kalau kebijakan pemdes sebelum dan sesudah uu desa saya kira sama saja" (Gatot Ferianto, Sekretaris BUMDesa)

\section{Pembahasan}

Mencermati hasil temuan di atas dan membandingkannya dengan pendapat Roscoe Pound ada beberapa hal yang mesti dicermati. Pertama, sebagaimana Roscoe Pound menyebut law as a tool of social engineering, yang dapat pula diartikan sebagai sarana yang ditujukan untuk mengubah perilaku warga masyarakat, sesuai dengan tujuan-tujuan yang telah ditetapkan sebelumnya (Soerjono, 2009) maka keberadaan UU No. 6 Tahun 2014 tentang Desa, yang menyebutkan secara eksplisit tentang peran perempuan dalam tiga ranah: politik, sosial, dan dan ekonomi di desa, memang dimaksudkan untuk mengubah perilaku masyarakat desa dan membentuk budaya baru yang lebih menempatkan perempuan sebagai mitra dalam tiga bidang tersebut. Kedua, UU No. 6 Tahun 2014 tentang Desa merupakan refkleksi dari "kemauan" negara. Kemuan negara adalah kemauan publik. Namun demikian harus juga dipertimbangkan bahwa hukum itu bukan seperti yang dikatakan oleh teori-teori positivis hukum bahwa hukum memiliki sifat tertutup, namun sebaliknya Pound melihat hukum sangat dipengaruhi oleh ideologi, politik, ekonomi, sosial, budaya. Hukum adalah suatu logika yang 
terbuka, perkembangan kebutuhan masyarakat sangat mempengaruhi pertumbuhan hukum di dalam masyarakat. Politik sangat mempengaruhi pertumbuhan hukum di dalam masyarakat. (Rasjidi, 2002)

Dengan demikian berlakunya UU No. 6 Tahun 2014 tentang Desa, utamanya yang berkenaan dengan pemberdayaan perempuan sangat bergantung pula bagaimana masyarakat desa bersangkutan mengkonstruksi peran perempuan di bidang politik, sosial, dan ekonomi. Dilihat dari temuan di atas, pemberdayaan politik perempuan lemah dibandingkan sosial dan ekonomi. Mengapa ? Karena konstruksi masyarakat desa bersangkutan belum menempatkan posisi perempuan sebagai mitra dalam pengambilan keputusan. Hal ini mempengaruhi kaum perempuan di desa untuk membatasi kiprahnya dalam prosesproses pengambilan keputusan karena keberadaan mereka sudah terwakili oleh para suami yang juga hadir dalam prosesproses pengambilan keputusan di desa. Meski ada beberapa perempuan yang sudah menduduki posisi sebagai perangkat desa, bahkan di posisi strategis sebagai sekretaris desa, namun kiprahnya masih sebatas mengeksekusi keputusan yang sudah diambil kepala desa melalui forum musyawarah desa. Tidak sekalipun ikut terlibat dalam penyusunan konsep apalagi andil dalam memutuskan kebijakan tingkat desa. Sebaliknya di ranah sosial dan ekonomi desa perempuan begitu dominan, karena para suami memang membuka ruang luas di dua bidang tersebut. Saat para suami pergi bekerja di luar rumah, maka perempuan aktif dalam kegiatan sosial dan ekonomi desa.

Dari pendapat Suskind yang melihat hukum dari dua aras yaitu legal service dan legal process menempatkan temuan riset dalam beberapa titik penting. Pertama, dari aras legal servis keberadaan UU No. 6 tahun 2014 tentang Desa mencerminkan pelayanan hukum dari negara bagi masyarakat desa. Kedua, dari dimensi legal process UU No. 6 Tahun 2014 tentang Desa merupakan legal problem solving sekaligus dispute resolution bagi masalah pemberdayaan perempuan di desa. Dengan demikian UU No, 6 Tahun 2014 tentang Desa merupakan janji hukum, yang oleh para pelakunya diupayakan seoptimal mungkin untuk dipenuhi.(Susskind, 1996)

\section{Simpulan dan Saran}

Bekerjanya hukum di ranah pemberdayaan politik perempuan antara Desa Lerep dan Desa Panggungharjo tidak berbeda secara signifikan. Keikutsertaan perempuan dalam pemerintahan desa memang secara kuantitatif lebih banyak di Desa Panggungharjo, namun secara substantif di kedua desa mengalami hal yang sama, tidak banyak perempuan yang ambil bagian dalam proses pengambilan keputusan 
desa. Kehadiran perempuan dalam proses tersebut rendah, apalagi dalam tataran mendiskusikan alternatif keputusan yang akan diambil.

Bekerjanya hukum di ranah pemberdayaan sosial perempuan menunjukkan ruang yang lebih terbuka bagi keterlibatan perempuan. Di bidang pendidikan, kesehatan, keagamaan sampai pemberdayaan masyarakat untuk pengentasan kemiskinan di desa, peran perempuan sangat kuat. Alasan klasik sering diutarakan seperti perempuan lebih rajin, tertib, sabar dalam menangani persoalan sosial dibanding laki-laki, meski dalam kenyataannya para perempuan aktivis sosial di dua desa cenderung lebih kuat memiliki komitmen dalam melaksanakan aktivitas sosial mereka.

Bekerjanya hukum di ranah pemberdayaan ekonomi perempuan di kedua desa menujukkan keterlibatan perempuan yang sangat tinggi. Keterlibatan tersebut terwadahi melalui Kelompok Wanita Tani (KWT) dan BUMDesa. Penghasilan tambahan yang diperoleh melalui KWT dan BUMDesa secara langsung memberikan dampak pada peningkatan ekonomi keluarga.

\section{DAFTAR PUSTAKA}

Alfirdause, L. K., \& Kushandajani, B. P. (2017). Gender and Village
Governance Transformation in Indonesia: An Initial Assessment. International Indonesia Forum, 2, 125 .

Retrieved from http://iif.or.id/2017-iif-working-paprseries/

Ashshofa, B. (2004). Metode Penelitian Hukum. Jakarta: Rineke Cipta.

Atmasasmita, R. (2012). Tiga Paradigma Hukum Dalam Pembangunan Nasional. Jurnal Hukum PRIORIS, 3(1), 1-26. Retrieved from https://media.neliti.com/media/publica tions/96217-ID-tiga-paradigmahukum-dalam-pembangunan-n.pdf

D.S. Andriansyah. (2015). Roscoe Pound: Law A Tool Of Social Engineering \& Sociological Jurisprudence. Blowrian Wordpress.Com. Retrieved from https://blowrian.wordpress.com/2015/ 03/26/roscoe-pound-law-a-tool-ofsocial-engineering-sociologicaljurisprudence/

Huijbers, T. (1982). Filsafat Hukum dalam Lintasan Sejarah. Yogyakarta: Kanisius.

Hunt, A. (1993). Explorations in Law and Society. New York: Routledge.

Kabeer, Naila and Natali, L. (2013). Gender Equality and Economic Growth: Is there a win-win? IDS Working Paper, 2013(417), 1-58. Retrieved from https://onlinelibrary.wiley.com/doi/10. 1111/j.2040-0209.2013.00417.x 
Kushandajani, K. (2016a). Implikasi UU No. 6 Tahun 2014 tentang Desa terhadap Penyelenggaraan Pemerintahan Desa. Jurnal Ilmiah Ilmu Pemerintahan, 2(6), 53-64. https://doi.org/10.14710/jiip.v2i1.1635

Kushandajani， K. (2016b). VILLAGE AUTHORITY BASED ON INDIGENOUS RIGHT AND LOCAL SCALE AUTHORITY: IMPLICATIONS OF LAW NO. 6/2014 TOWARD VILLAGE AUTHORITY (pp. 111-119). Unevsitas Muhammadiyah Yogyakarta. Retrieved from http://repository.umy.ac.id/bitstream/h andle/123456789/2869/Proceeding ICSP 2016 UMY.pdf?sequence $=1 \&$ isAllowed $=\mathrm{y}$

Luhmann, N. (1985). A Sociological Theory of Law. London: Routledge and Kegan Paul.

Marbun, R. (2014). Grand Design Poli k Hukum Pidana dan Sistem Hukum Pidana Indonesia Berdasarkan Pancasila dan Undang-Undang Dasar Negara Republik Indonesia 1945 A . Pendahuluan Sejak era tahun tujuh puluhan , masyarakat hukum Indonesia sangat mengenal ungkapan “ hukum seb. Padjadjaran Jurnal Ilmu Hukum, 1(3), 558-577. Retrieved from http://jurnal.unpad.ac.id/pjih/article/vi ew/7095
Mujahid, N., Ali, M., Noman, M., \& Azeema Begum. (2015). Dimensions of Women Empowerment: A case study of Pakistan Dimensions of Women Empowerment: A case study of Pakistan. Journal of Economics and Sustainable Development, 6(1), 37-45. Retrieved from https://www.researchgate.net/profile/ Muhammad_Noman44/publication/31 9099845_Dimensions_of_Women_E mpowerment_A_case_study_of_Pakis tan/links/5bc4b26ea6fdcc03c788b17f/ Dimensions-of-WomenEmpowerment-A-case-study-ofPakistan.pdf

Nasution, S. (1996). Metode Penelitian Naturalistik Kualitatif. Bandung: Transito.

Nayak, P., \& Bidisha Mahanta. (2009). Women empowerment in India. SSRN Electronic Journal, (February), 1-32. https://doi.org/10.1007/978-981-104268-3_1

Nurcholis. (2014). Undang-Undang No. 6 Tahun 2014 tentang Desa Dilihat dari Pasal 18 B Ayat 2 UUD 1945. Masalah-Masalah Hukum, 43(1), 149159. Retrieved from https://ejournal.undip.ac.id/index.php/ $\mathrm{mmh} /$ issue/view/1505

Rahardjo, S. (2006). Ilmu Hukum. Bandung: Citra Aditya Bakti.

Rahman, M. . A. (2013). Women's 
Empowerment: Concept and Beyond. Global Journal of Human Social Science, 13(6). https://doi.org/10.1006/fstl.1998.0319

Rasjidi, L. dan I. T. R. (2002). Pengantar Filsafat Hukum. Bandung: Mandar Maju.

Sandefur, R. L. (2015). When Is Law in Action? Ohio State Law Journal Furthermore, 77(59), 59-64. Retrieved from http://moritzlaw.osu.edu/students/grou ps/oslj/files/2016/03/Vol.-77-59-64Sandefur-Response.pdf

Sinha, S. P. (1993). Jurisprudence: Legal Philosophy in A Nutshell. Minnesota: West Publishing Co.

Soerjono, S. (2009). Pokok-Pokok Sosiologi Hukum. Jakarta: Rajawali Press.

Sundaram, S., Sekar, M., and Subburaj, A. (2014). Women Empowerment: Role of Education. Ijmss, 2(12), 76-85. Retrieved from https://www.researchgate.net/profile/S ekar_M2/publication/280218999_WO MEN_EMPOWERMENT_ROLE_OF _EDUCATION/links/55ade53608aee0 79921e3e4a/WOMEN-
EMPOWERMENT-ROLE-OFEDUCATION.pdf

Susskind, R. (1996). The Future of law Facing the Challenges of Information Technology. Oxford: Clarendon Press. Turkel, G. (1996). Law and Society: Critical Approaches. Boston: Allyn \& Bacon.

Warassih, E. (2005). Pranata Hukum: Sebuah Telaah Sosiologis. Semarang: Suryandaru Utama.

Welly, A. (2016). IMPLEMENTASI UNDANG-UNDANG NO.6 TAHUN 2014 TENTANG DESA STUDI KASUS PELAKSANAAN TUGAS KEPALA DESA DI DESA GEMAR BARU KECAMATAN MUARA ANCALONG KABUPATEN KUTAI TIMUR. EJournal Ilmu Pemerintahan, 4(2), 829-842. Retrieved from http://ejournal.ip.fisipunmul.ac.id/site/wpcontent/uploads/2016/06/Antonius Welly (06-20-16-01-32-35).pdf Wignjosoebroto, S. (2002). Hukum: Paradigma, Metode dan Dinamika Masalahnya. Jakarta: ELSAM dan HUMA. 